\title{
CROSS-SECTIONAL STUDY AMONG MEDICAL STUDENTS IN LATVIA: DIFFERENCES OF MENTAL SYMPTOMS AND SOMATIC SYMPTOMS AMONG LATVIAN AND INTERNATIONAL STUDENTS
}

\author{
Kamiar-Kersten Rueckert, Gunta Ancane
}

Riga Stradinš University, Riga, Latvia

\begin{abstract}
Introduction. This research aims to determine the prevalence of mental symptoms (depressive symptoms, anxiety and adjustment disorders) and somatic symptoms among medical students at Riga Stradins University in Latvia, as well as to display the differences between local and international medical students.

Methods. A cross-sectional study was conducted by means of onlinebased questionnaires among medical students in their $1^{\text {st }}, 4^{\text {th }}$ and $6^{\text {th }}$ years studying in Riga, Latvia, during March 2017. The mental and somatic symptoms were screened with the PHQ-D Option C (PHQ-15, PHQ-9, GAD-7). Symptoms of adjustment disorder were obtained by the ADNM-6. Medical students were divided into three groups according to their answers of the PHQ-D: Group A: no symptom, group B: a single symptom, group C: multiple symptoms. A general questionnaire and a questionnaire regarding stressful life events over the past half-year were distributed additionally.

Results. 67 (40.1\%) participants were Latvian students; 100 (59.9\%) were international students. 23 (34.3\%) Latvian students were in group A, 20 (29.9\%) in group B, $24(35.8 \%)$ in group C. 51 (51\%) international students were in group A, 34 (34\%) in group B, 14 (14\%) in group C. Latvians displayed statistically significantly more health-related symptoms (0.003). 11 (11\%) international students who reported a stressful life event over the last half-year were in group C. 21 (31.3\%) of Latvian students who reported a stressful life event over the last half-year were in group C. 73 (43.7\%) of all students had experienced stressful life events and displayed troubles adjusting to them. 65 (63.1\%) students of the two groups with a stressful life found the event to have a great burden on them, $63(61.2 \%)$ were wondering whether it could happen again, and $73(70.9 \%)$ tried to suppress their feelings.

Conclusion. Medical students in Latvia have a high prevalence of healthrelated symptoms. Latvian medical students display more health-related
\end{abstract}


symptoms and symptoms of adjustment disorder. Further research needs to be performed to investigate whether Latvians have a lower threshold for stressors or whether they are exposed to more stressors than international students. The high prevalence of symptoms of adjustment disorder may impact the prospective patient-doctor relationship and the treatment outcome.

Keywords: cross-sectional studies; depressive disorder/etiology; medical education; medical students; anxiety; adjustment disorder; mental health

\section{INTRODUCTION}

Medical students are known to have high levels of depressive symptoms and anxiety $[1,2]$. Depressive symptoms and anxiety can be described as mental symptoms. Increased mental symptoms are often connected with increased somatic symptoms $[1,2,3]$. No consistent value for mental distress among medical students are present [4]. A previous research among the group of tested medical students suggests clinically relevant depressive symptoms among 23.5\% [5]. This research aims to determine the prevalence of mental symptoms, somatic symptoms and symptoms of adjustment disorder among medical students in Latvia as well as to display the differences between local and international medical students.

\section{MATERIAL AND METHODS}

Subjects. A cross-sectional study was conducted by means of online-based questionnaires among medical students studying in Riga, Latvia, during March 2017. The questionnaires were distributed anonymously among $1^{\text {st }}, 4^{\text {th }}$ and $6^{\text {th }}$ year students to assess changes throughout the educational process. The questionnaires were distributed during the middle of the semester in March 2017 to avoid falsified results during the exam period. The study was approved by the medical ethics board of Riga Stradinš University, Latvia.

Study variables. The mental symptoms were screened with the PHQ-D Option C and the ADNM-6. The PHQ-D Option C consists of three questionnaires regarding somatoform disorders (PHQ-15), depressive disorders (PHQ-9) and generalized anxiety disorders (GAD-7). No control was performed by doctors; therefore, somatoform disorders will be referred to as somatic symptoms, depressive disorders will be referred to as depressive symptoms and generalized anxiety disorder will be referred to as anxiety. The questionnaires PHQ-9, PHQ-15 and the GAD-7 had cut-off scores (Table 2).

The PHQ-15 consists of 15 items which measure the burden of common somatic symptoms. The validity and reliability are well tested and proven [6]. 
The PHQ-9 consists of 9 items which fulfil the key criteria for major depression according to DSM-5 and ICD 10. It is broadly used in the primary care setting as well as in research with a well-tested validity and reliability $[7,8]$. The GAD-7 consists of seven items which assess the DSM- 5 core criteria of generalized anxiety disorder with a well-tested validity and reliability [9].

The students were divided up into three groups according to their PHQ-9, PHQ-15 and GAD-7 replies: Group A: no symptom, group B: a single symptom, group C: multiple symptom.

A general questionnaire, a questionnaire regarding stressful life events over the past half-year and the ADNM- 6 were distributed. The ADNM-6 is a validated screening scale for adjustment disorders $[10,11]$. The questionnaire concerning stressful life events during the previous half-year consisted of 10 possible events: (1) no history of a stressful life event during the past half-year, (2) family conflict, (3) divorce of parents, (4) separation, (5) conflict in university/work life/ with roommates, (6) adjustment to university life, (7) immigration or moving to a new home, (8) financial problems, (9) illness or death of a loved one, (10) ill success or setbacks in the educational process. These ten answers made up five psychosocial clusters (Table 3 ).

The mental symptoms and somatic symptoms are summarized under the term "health-related symptoms" in this article.

Statistical analysis. The data was analysed with IBM SPSS Version 21.

\section{RESULTS}

167 (90.3\%) participants filled out the questionnaires correctly. 67 (40.1\%) were Latvian students and 100 (59.9\%) were international students. The international students' origins were: 8 (8\%) Finland, 41 (41\%) Germany, 11 (11\%) Norway, 17 (17\%) Sweden, 22 (22\%) others. Depressive symptoms among Latvian students were present in 28 (41.8\%) students, somatic symptoms in 27 (40.3\%) and anxiety in 21 (31.3\%) students. Depressive symptoms among international students were present in 20 (20\%) students, somatic symptoms in $36(36 \%)$ and anxiety in $14(14 \%)$ students.

$23(34.3 \%)$ Latvian students were in group A, 20 (29.9\%) in group B, $24(35.8 \%)$ in group C. 51 (51\%) international students were in group A, 34 (34\%) in group B, 14 (14\%) in group C. Latvians displayed statistically significantly more health-related symptoms $(0.003) .13$ (76.5\%) of Latvian $6^{\text {th }}$ year students and $20(66.6 \%)$ of the $1^{\text {st }}$ year students displayed single or multiple symptoms. 39 (69.6\%) Latvian female students displayed health-related symptoms. 5 (53.7\%) International students older than 27 years displayed healthrelated symptoms. 
Table 1. Health-related symptoms' distribution among the sample.

\begin{tabular}{|c|c|c|c|c|c|}
\hline \multirow{3}{*}{ Sample } & & Group A & Group B & Group C & \multirow{3}{*}{ Differences } \\
\hline & $\begin{array}{c}\text { Complete } \\
\text { sample }\end{array}$ & $\begin{array}{c}\text { No } \\
\text { symptom }\end{array}$ & $\begin{array}{c}\text { Single } \\
\text { symptom }\end{array}$ & $\begin{array}{l}\text { Multiple } \\
\text { symptoms }\end{array}$ & \\
\hline & $n=167$ & $n=75(44.9)$ & $n=54(32)$ & $n=38(22.8)$ & \\
\hline Latvian students & $\mathrm{n}=67$ & & & & \\
\hline \multicolumn{6}{|l|}{ Gender } \\
\hline male & $11(16.4)$ & $6(54.5)$ & $2(18.2)$ & $3(27.3)$ & $A>C>B$ \\
\hline female & $56(83.6)$ & $17(30.4)$ & $18(32.1)$ & $21(37.5)$ & $C>B>C$ \\
\hline \multicolumn{6}{|l|}{ Age group } \\
\hline $18-20$ & $27(40.3)$ & $8(29.6)$ & $7(25.9)$ & $12(44.4)$ & $C>A>B$ \\
\hline $21-23$ & $16(23.9)$ & $9(56.3)$ & $3(18.8)$ & $4(25.0)$ & $A>C>B$ \\
\hline $23-26$ & $23(34.3)$ & $6(26.1)$ & $9(39.1)$ & $8(34.8)$ & $B>C>A$ \\
\hline$>27$ & $1(1.5)$ & $0(0)$ & $1(100)$ & $0(0)$ & $B>A, C$ \\
\hline \multicolumn{6}{|l|}{ Study year } \\
\hline $1^{\text {st }}$ year & $30(44.8)$ & $10(33.3)$ & $7(23.3)$ & $13(43.3)$ & $C>B>A$ \\
\hline $4^{\text {th }}$ year & $20(29.9)$ & $9(45.0)$ & $6(30.0)$ & $5(25.0)$ & $A>B>C$ \\
\hline $6^{\text {th }}$ year & $17(25.4)$ & $4(23.5)$ & $7(41.2)$ & $6(35.3)$ & $B>C>A$ \\
\hline $\begin{array}{l}\text { International } \\
\text { students }\end{array}$ & $n=100$ & & & & \\
\hline \multicolumn{6}{|l|}{ Gender } \\
\hline male & $45(45.5)$ & $26(57.8)$ & $11(24.4)$ & $8(17.8)$ & $A>B>C$ \\
\hline female & $54(54.5)$ & $25(46.3)$ & $23(42.6)$ & $6(11.1)$ & $A>B>C$ \\
\hline \multicolumn{6}{|l|}{ Age group } \\
\hline $18-20$ & $35(35.0)$ & $17(48.6)$ & $14(40.0)$ & $4(11.4)$ & $A>B>C$ \\
\hline $21-23$ & $26(26.0)$ & $15(57.7)$ & 7 (26.9) & $4(15.4)$ & $A>B>C$ \\
\hline $23-26$ & $32(32.0)$ & $18(56.3)$ & $12(37.5)$ & $2(6.3)$ & $A>B>C$ \\
\hline$>27$ & $7(7.0)$ & 2 (28.6) & 1 (14.3) & $4(57.1)$ & $C>A>B$ \\
\hline \multicolumn{6}{|l|}{ Study year } \\
\hline $1^{\text {st }}$ year & $56(56.0)$ & $27(48.2)$ & $22(39.3)$ & $7(12.5)$ & $A>B>C$ \\
\hline $4^{\text {th }}$ year & $20(20.0)$ & $12(60.0)$ & $4(20.0)$ & $4(20)$ & $A>B, C$ \\
\hline $6^{\text {th }}$ year & $24(24.0)$ & $13(54.2)$ & $8(33.3)$ & $3(12.5)$ & $A>B>C$ \\
\hline
\end{tabular}

Group A: Individuals exceeding no cut-off score (PHQ-9 > 10, PHQ-15 >10, GAD-7 > 10) Group B: Individuals exceeding one cut-off score Group C: Individuals exceeding two or more cut-off scores.

*Gender (other) excluded for statistical reasons 
Table 2 displays the students' health-related symptom groups in connection with the psychosocial clusters. The vast majority of international students who reported a stressful life event over the last half-year was in group A or B. The vast majority of Latvian students who reported a stressful life event over the last half-year was in group B or C.

Table 2. Health-related symptoms in distribution among psychosocial clusters.

\begin{tabular}{|c|c|c|c|c|c|}
\hline \multirow[b]{3}{*}{ Cluster } & \multicolumn{2}{|r|}{ Group A } & \multirow{2}{*}{$\begin{array}{c}\text { Group B } \\
\text { Single } \\
\text { symptom }\end{array}$} & Group C & \multirow[b]{2}{*}{$\begin{array}{l}\text { Differ- } \\
\text { ences }\end{array}$} \\
\hline & $\begin{array}{l}\text { Complete } \\
\text { sample }\end{array}$ & $\begin{array}{c}\text { No } \\
\text { symptom }\end{array}$ & & $\begin{array}{l}\text { Multiple } \\
\text { symptoms }\end{array}$ & \\
\hline & $\begin{array}{c}n=167 \\
(100)\end{array}$ & $n=75$ & $n=54$ & $\mathrm{n}=38$ & \\
\hline Latvian students & $\mathrm{n}=67$ & $\mathrm{n}=23(34.3)$ & $\mathrm{n}=20(29.9)$ & $n=24(35.8)$ & $C, A>B$ \\
\hline No stressful life event & $16(23.9)$ & $8(50.0)$ & $5(31.3)$ & $3(18.8)$ & $A>B>C$ \\
\hline Problems with family & $28(41.8)$ & $7(25.0)$ & $13(46.4)$ & $8(28.6)$ & $B>A, C$ \\
\hline Immigration & $7(10.4)$ & $1(14.3)$ & $3(42.9)$ & $3(42.9)$ & $\mathrm{B}, \mathrm{C}>\mathrm{A}$ \\
\hline University life & $32(47.8)$ & $12(37.5)$ & $6(18.8)$ & $14(43.8)$ & $C>A>B$ \\
\hline Personal problems & $28(41.8)$ & $9(32.1)$ & $8(28.6)$ & $11(39.3)$ & $C>A>B$ \\
\hline $\begin{array}{l}\text { International } \\
\text { students }\end{array}$ & $n=100$ & $\mathrm{n}=52(51.0)$ & $\mathrm{n}=34(34.0)$ & $\begin{array}{l}n=14 \\
(14.0)\end{array}$ & $A>B>C$ \\
\hline $\begin{array}{l}\text { No stressful life } \\
\text { event }\end{array}$ & $34(34.0)$ & $23(67.6)$ & $8(23.5)$ & $3(8.8)$ & $A>B>C$ \\
\hline Problems with family & $41(41.0)$ & $20(48.8)$ & $14(34.1)$ & $7(17.1)$ & $A>B>C$ \\
\hline Immigration & $27(27.0)$ & $11(40.7)$ & $11(40.7)$ & $5(18.5)$ & $A, B>C$ \\
\hline University life & $56(56.0)$ & $20(35.7)$ & $22(39.3)$ & $14(25.0)$ & $A, B>C$ \\
\hline Personal problems & $25(25.0)$ & $10(40.0)$ & $10(40.0)$ & $5(20.0)$ & $A, B>C$ \\
\hline
\end{tabular}

Group A: Individuals exceeding no cut-off score Immigration (7)

(PHQ-9 > 10, PHQ-15 >10, GAD-7 > 10)

Group B: Individuals exceeding one cut-off score University life $(5,6)$

Group C: Individuals exceeding two or more cut- Personal Problems $(4,8,10)$ off scores.

73 (43.7\%) of all students had experienced stressful life events and displayed troubles adjusting to them (Table 3). Latvian students adjusted worse to previous stressful life events than international students. 65 (63.1\%) student of the two groups with a stressful life found the event to have a great burden on them, 63 (61.2\%) were wondering whether it could happen again and $73(70.9 \%)$ tried to suppress their feelings. 
Table 3. Symptoms of adjustment disorder to a stressful life event.

\begin{tabular}{l|c|c|c|c}
\hline $\begin{array}{l}\text { Total number of students with } \\
\text { a stressful life event* }\end{array}$ & $\begin{array}{c}\text { Latvian } \\
\text { Students } \\
\mathbf{n = 4 5}\end{array}$ & $\begin{array}{c}\text { Internation- } \\
\text { al students } \\
\mathbf{n}=58\end{array}$ & $\begin{array}{c}\text { Total } \\
\mathbf{n = 1 0 3}\end{array}$ & $\begin{array}{c}\text { Differ- } \\
\text { ence }\end{array}$ \\
\hline $\begin{array}{l}\text { 1. I keep having to think about the } \\
\text { stressful situation and this a great } \\
\text { burden to me }\end{array}$ & $31(68.9)$ & $34(58.6)$ & $65(63.1)$ & LV > INT \\
\hline $\begin{array}{l}\text { 2. I wonder whether something like } \\
\text { this could happen to me again }\end{array}$ & $28(62.2)$ & $35(60.3)$ & $63(61.2)$ & LV, INT \\
\hline $\begin{array}{l}\text { 3. Since the stressful situation, } \\
\text { I can no longer sleep properly }\end{array}$ & $10(22.2)$ & $11(19.0)$ & $21(20.4)$ & LV, INT \\
\hline $\begin{array}{l}\text { 4. Since the stressful situation, } \\
\text { I don't like going to work or carrying } \\
\text { out the necessary tasks in everyday } \\
\text { life }\end{array}$ & $17(37.8)$ & $12(20.7)$ & $29(29.0)$ & LV > INT \\
\hline $\begin{array}{l}\text { 5. Since the stressful situation, } \\
\text { I have withdrawn from my family or } \\
\text { friends/acquaintances }\end{array}$ & $15(33.3)$ & $13(22.4)$ & $28(27.9)$ & LV > INT \\
\hline $\begin{array}{l}\text { 6. I try to suppress my feelings because } \\
\text { they are a burden to me }\end{array}$ & $31(68.9)$ & $42(72.4)$ & $73(70.9)$ & LV, INT \\
\hline
\end{tabular}

*The number is decreased due to missing answers about a stressful life event; the percentage and total are based on the response.

\section{CONCLUSION}

Latvian and international medical students have a heightened prevalence of mental and somatic symptoms. The level of depressive symptoms and anxiety are higher than in the general population $[12,13]$, yet it is doubtful that the mental symptom levels differ in respect to other specialities of higher education $[14,15]$. Latvian students displayed a higher prevalence of health-related symptoms and symptoms of adjustment disorder. Further research needs to be performed to investigate whether Latvians have a lower threshold for stressors, or whether they are exposed to more stressors than international students. Latvia's growing social inequality [16] should be discussed as a major extrinsic factor contributing to the higher prevalence of health-related symptoms.

Table 3 displays symptoms of adjustment disorder. Answers 1, 2, and 6 can be described as a self-reflective burden. Answers 3, 4, and 5 can be described as a functional burden. On average $64.7 \%$ of the students suffered from the self-reflective burden, while $25.7 \%$ suffered from a functional burden. ChewGraham et al. emphasize that medical students are reluctant to express signs of 
vulnerability [17]. The difference between the functional and the self-reflective burden might be found in the secretive character of the latter, while a functional burden could express vulnerability and be subjectively regarded as a felt weakness of character by outsiders.

$70.9 \%$ of medical students tried to suppress their negative feelings connected to the stressful life event because they were a burden. This could have a serious impact on the prospective treatment outcome, which emphasizes the patientdoctor relationship and the patient's subjective experience of "feeling felt" as the key factors for a successful treatment $[18,19]$. It is questionable whether medical students who try to suppress their feelings can acknowledge the negative emotions of patients connected to their illness, display empathy and form a successful patient-doctor relationship. We believe medical students who do not acknowledge their emotions experience, have higher health-related symptoms, which opens up room for further research.

\section{REFERENCES}

1. Hamilton M. (1989). Frequency of symptoms in melancholia (depressive illness). Br J Psychiatry, 154, 201-206.

(URL: https://www.ncbi.nlm.nih.gov/pubmed/2775946)

2. Kroenke K. (2003). The interface between physical and psychological symptoms. Prim Care Companion J Clin Psychiatry; 5, 11-18.

3. Simon G., Korff von M., Piccïnellï M., et al. (1999). An international study of the relation between somatic symptoms and depression. N Engl J Med, 341, 1329-1335. (URL: https://www.ncbi.nlm.nih.gov/pubmed/10536124)

4. Hope V., Henderson M. (2014). Medical student depression, anxiety and distress outside North America: a systematic review. Med Educ., 48, 10, 963-79. (URL: https://www.ncbi.nlm.nih.gov/pubmed/25200017)

5. Rueckert K.-K. (2016). Quality of Life and Depression in German Medical Students at foreign universities. RSU International Conference Health and Social Science. p. 168.

(http://www.rsu.lv/eng/images/Documents/isc_2016_abstracts/depression_ medical_students.pdf)

6. Kroenke K., Spitzer R.L., Williams J.B. (2002). The PHQ-15: Validity of a New Measure for evaluating the Severity of Somatic Symptoms. Psychosom Med, 64, 258-66 (URL: https://www.ncbi.nlm.nih.gov/pubmed/11914441)

7. Kroenke K., Spitzer R.L., Williams J.B. (2001). The PHQ-9. Validity of a New Measure for Evaluating the Severity of Somatic Symptoms. Psychosom Med, $16,606-13$

8. Kroenke K., Spitzer R.L., Williams J.B. (2001) The PHQ-9: validity of a brief depression severity measure. J Gen Intern Med, 16, 9, 606-613. 
(URL: https://www.ncbi.nlm.nih.gov/pubmed/11556941)

9. Loewe B., Decker O., Müller S., Brähler E., Schellberg D., Herzog W., Herzberg P.Y. (2008). Validation and standardization of the Generalized Anxiety Disorder Screener (GAD-7) in the general population. Med Care, 46, 3, 266-74 (Abstract)

10. Einsle F., Köllner V., Dannemann S., Maercker A. (2010). Development and validation of a self- report for the assessment of adjustment disorders. Psychology, Health \& Medicine, 15, 584-595

(URL: https://www.ncbi.nlm.nih.gov/pubmed/20835968)

11. Glaesmer H., Rompel M., Braehler E., Hinz A., Maercker A. (2015). Adjustment disorder as pro- posed for ICD-11: Dimensionality and symptom differentiation. Psychiatry Res, 229, 3, 940-948 (Abstract)

12. Waraich P., Goldner E.M., Somers J.M., Hsu L. (2004). Prevalence and incidence studies of mood disorders: a systematic review of the literature. Can J Psychiatry, 49, 2, 124-138. (https://www.ncbi.nlm.nih.gov/pubmed/15065747)

13. Somers J.M., Goldner E.M., Waraich P., Hsu L. (2006). Prevalence and incidence studies of anxiety disorders: a systematic review of the literature. Can J Psychiatry, 51, 2, 100-113. (URL: https://www.ncbi.nlm.nih.gov/pubmed/16989109)

14. Firth-Cozens J. (2001). Medical student stress. Med Educ, 35, 1, 6-7. (URL: https://www.ncbi.nlm.nih.gov/pubmed/11123587)

15. Puthran R., Zhang M.W., Tam W.W., Ho R.C. (2016). Prevalence of depression amongst medical students: a meta-analysis. Med Educ, 40, 4, 456-468.

(URL: https://www.ncbi.nlm.nih.gov/pubmed/26995484)

16. OECD. (2016). OECD Reviews of Labour Market and Social Policies: Latvia 2016, OECD Publishing, Paris.

(http://www.oecd.org/publications/oecd-reviews-of-labour-market-and-socialpolicies-latvia-2016-9789264250505-en.htm)

17. Chew-Graham C.A., Rogers A., Yassin N. (2003). "I wouldn't want it on my CV or their records": medical students' experiences of help-seeking for mental health problems. Med Educ, 37, 10, 873-880.

(URL: https://www.ncbi.nlm.nih.gov/pubmed/12974841)

18. Mikesell L. (2013). Medicinal Relationships: caring conversations. Med Educ, 47, 443-452. (http://www.academia.edu/24708263/Medicinal_relationships_ caring_conversation)

19. Siegel D. (1999). The Developing Mind. New York: Guilford Press, 149.

\section{Address for correspondence:}

Kamiar-K. Rueckert

Blaumana iela 5A dz. 24

Riga, LV-1010

+37120191073

Kamiar.rueckert@gmx.net

016221@rsu.edu.lv
Prof. Dr. med Gunta Ancane

Kapselu iela 23

Riga, LV-1046

+37129440440

Gunta.Ancane@rsu.lv 